\title{
Histone deacetylase inhibition accelerates the early events of stem cell differentiation: transcriptomic and epigenetic analysis Efthimia Karantzali ${ }^{* \dagger}$, Herbert Schulz ${ }^{\ddagger}$, Oliver Hummel ${ }^{\ddagger}$, Norbert Hubner ${ }^{\ddagger}$, AK Hatzopoulos ${ }^{\S \uparrow}$ and Androniki Kretsovali*
}

\begin{abstract}
Addresses: *Institute of Molecular Biology and Biotehnology, FORTH, Heraklion 71110 Greece. ${ }^{\dagger}$ Department of Biology, University of Crete, Heraklion 71409 Greece. ${ }^{*}$ Max-Delbruck-Center for Molecular Medicine-MDC, Berlin 13092, Germany. §GSF, Institute of Clinical Molecular Biology and Tumor Genetics, 81377 Munich, Germany. "Vanderbilt University, Department of Medicine - Division of Cardiovascular Medicine and Department of Cell and Developmental Biology, Nashville Nashville, TN 37232-2358, USA.
\end{abstract}

Correspondence: Androniki Kretsovali. Email: kretsova@imbb.forth.gr

Published: 4 April 2008

Genome Biology 2008, 9:R65 (doi:10.1186/gb-2008-9-4-r65)

The electronic version of this article is the complete one and can be found online at http://genomebiology.com/2008/9/4/R65
Received: 17 October 2007

Revised: 14 January 2008

Accepted: 4 April 2008

(C) 2008 Karantzali et al.; licensee BioMed Central Ltd.

This is an open access article distributed under the terms of the Creative Commons Attribution License (http://creativecommons.org/licenses/by/2.0), which permits unrestricted use, distribution, and reproduction in any medium, provided the original work is properly cited.

\begin{abstract}
Background: Epigenetic mechanisms regulate gene expression patterns affecting cell function and differentiation. In this report, we examine the role of histone acetylation in gene expression regulation in mouse embryonic stem cells employing transcriptomic and epigenetic analysis.

Results: Embryonic stem cells treated with the histone deacetylase inhibitor Trichostatin A (TSA), undergo morphological and gene expression changes indicative of differentiation. Gene profiling utilizing Affymetrix microarrays revealed the suppression of important pluripotency factors, including Nanog, a master regulator of stem cell identity, and the activation of differentiationrelated genes. Transcriptional and epigenetic changes induced after 6-12 hours of TSA treatment mimic those that appear during embryoid body differentiation. We show here that the early steps of stem cell differentiation are marked by the enhancement of bulk activatory histone modifications. At the individual gene level, we found that transcriptional reprogramming triggered by histone deacetylase inhibition correlates with rapid changes in activating K4 trimethylation and repressive $\mathrm{K} 27$ trimethylation of histone $\mathrm{H} 3$. The establishment of $\mathrm{H} 3 \mathrm{~K} 27$ trimethylation is required for stable gene suppression whereas in its absence, genes can be reactivated upon TSA removal.
\end{abstract}

Conclusion: Our data suggest that inhibition of histone deacetylases accelerates the early events of differentiation by regulating the expression of pluripotency- and differentiation-associated genes in an opposite manner. This analysis provides information about genes that are important for embryonic stem cell function and the epigenetic mechanisms that regulate their expression.

\section{Background}

Embryonic stem (ES) cells have attracted intense interest because they offer great promise for tissue regeneration in cell-based therapies. In addition, they provide an excellent experimental system to study development and differentiation using in vivo and in vitro strategies. 
ES cells can be cultivated in vitro while retaining their undifferentiated character and self-renewing capacity [1,2]. Signal transduction mechanisms implicated in self-renewal are the LIF/Stat3 pathway for murine ES cells [3], and bone morphogenetic protein [4] and the Wnt pathway [5] for both mouse and human stem cells. Intrinsic factors that maintain selfrenewal include the transactivators Oct4, Sox2 and Nanog [1]. The three transcription factors form a regulatory circuit that has auto- and cross-regulatory activities [6] and is associated with both active and silenced genes [6,7]. This initial 'stemness core' has been recently extended by the addition of Klf4 [8] and Sall4 [9]. Moreover, novel factors that contribute to pluripotency have been identified using an RNA interference approach [10] or Nanog affinity co-purification strategies [11]. These new discoveries suggest that regulation of stemness may be far more complex than previously thought.

Superimposed on this genetic program, epigenetic mechanisms may also determine the composition of the stem cell transcriptome. Post-translational modifications of histones are indicative of chromatin structure and regulate gene activation and repression during development [12,13]. For example, lysine acetylation of various residues on histone $\mathrm{H}_{3}$ and $\mathrm{H}_{4}$ and lysine methylations of $\mathrm{H}_{3} \mathrm{~K}_{4}, \mathrm{H}_{3} \mathrm{~K}_{3} 6$ and $\mathrm{H}_{3} \mathrm{~K}_{79}$ are involved in transcriptional activation whereas methylation of $\mathrm{H}_{3} \mathrm{~K} 9, \mathrm{H}_{3} \mathrm{~K} 27$ and $\mathrm{H}_{4} \mathrm{~K} 2 \mathrm{O}$ are linked to transcriptional silencing [14]. The chromatin of ES cells has a characteristic structure of increased accessibility compared to differentiated cells, due to fewer and loosely bound histones and architectural proteins [15]. Trimethylation of $\mathrm{K}_{4}$ and K27, mediated by Trithorax and Polycomb groups, respectively, have important functions in the determination of stem cell state and differentiation commitment $[16,17]$. Lineage-specific genes, which are silenced in the undifferentiated state by polycomb complexes [18,19], are 'bivalently' marked with both modifications $[16,17,20-22]$. This mark is considered a means of keeping developmental genes poised for rapid activation during stem cell differentiation $[20,21]$, although it is neither a unique feature of ES cells $[16,17,23]$ nor a prerequisite for rapid transcriptional response [17]. These findings suggest that epigenetic mechanisms have important roles in stem cell identity $[24,25]$, but may also guide differentiation and fate decisions $[26,27]$.

In this light, molecular tools that disrupt global epigenetic mechanisms have the potential to reveal the broader spectrum of genetic circuits operating in stem cells. Among them, the pharmacological agent Trichostatin A (TSA) is particularly potent, inhibiting the enzymatic activity of deacetylases and thus promoting histone acetylation. TSA, by its universal action, provides an entry-point for an overall assessment of the importance of histone modifications on stem cell biology.

To evaluate the importance of histone acetylation on ES cell differentiation, we treated cells with the histone deacetylase inhibitor TSA and examined gene expression changes using
Affymetrix gene chips and epigenetic changes using chromatin immunoprecipitation (ChIP) assays. TSA treatment leads to down-regulation of Nanog along with a large group of genes that are characteristic of the undifferentiated state and up-regulation of mesodernal and neuro-ectodermal marker genes. We show here that TSA accelerates the early stages of stem cell differentiation by the global increase of activatory histone modifications and gene-specific changes in the balance between $\mathrm{K}_{4}$ and K27 trimethylations. Both gene expression and epigenetic changes resemble those that appear during embryoid body differentiation.

\section{Results \\ Inhibition of histone deacetylase activity induces phenotypic changes and Nanog suppression in undifferentiated ES cells}

To examine the role of histone acetylation on the differentiation state of mouse ES cells, we employed the histone deacetylase inhibitor TSA. We first tested the effect of different TSA concentrations on the mouse CGR8 ES cell line cultivated in the presence of LIF. When 10-50 $\mathrm{nM}$ concentrations were used, we observed morphological changes that depended on the concentration and duration of the treatment (not shown). Figure 1a shows a phase contrast morphology and alkaline phosphatase staining (ALP) of mES cells subjected to $50 \mathrm{nM}$ TSA for $12 \mathrm{~h}$. Control cells form round and compact colonies, which stain $>90 \%$ positive for ALP. After treatment with 50 nM TSA for $12 \mathrm{~h}, 70 \%$ of the colonies are disrupted and the cells become flattened and negative for ALP; the other $30 \%$ show a loose morphology containing a mixed population of ALP-positive and -negative cells.

To identify possible molecular changes underlying the TSAinduced phenotypic transformation, we analyzed the expression of Nanog, one of the master regulators of ES cell identity. Nanog is down-regulated by TSA in a dose-dependent manner, with a concentration of $50 \mathrm{nM}$ having maximal effect (Figure $\mathrm{S} 1 \mathrm{~A}$ in Additional data file 1). Figure $1 \mathrm{~b}$ shows that Nanog mRNA levels decline very rapidly starting within the first $2 \mathrm{~h}$ of treatment with $50 \mathrm{nM}$ TSA and are minimal by $4 \mathrm{~h}$. Nanog protein levels drop with slower kinetics (Figure 1b). Similar to Nanog, Oct4 and Sox2 mRNA (Figure S2 in Additional data file 1) and protein levels (Figure S1B in Additional data file 1) were reduced during TSA treatment.

In order to test if the rapid Nanog suppression is due to transcriptional silencing, we examined the effect of TSA on the activity of different Nanog promoter fragments cloned in front of the luciferase reporter gene (Figure 1c). Two Nanog promoter fragments extending 966 or 220 bp upstream from the transcriptional start site are both suppressed by TSA (Figure 1c, -966, -220). The proximal promoter has higher activity, possibly because it is deprived of negative regulatory elements that reside within upstream regions. Interestingly, when the Nanog enhancer, located $5 \mathrm{~kb}$ upstream of the 
(a)

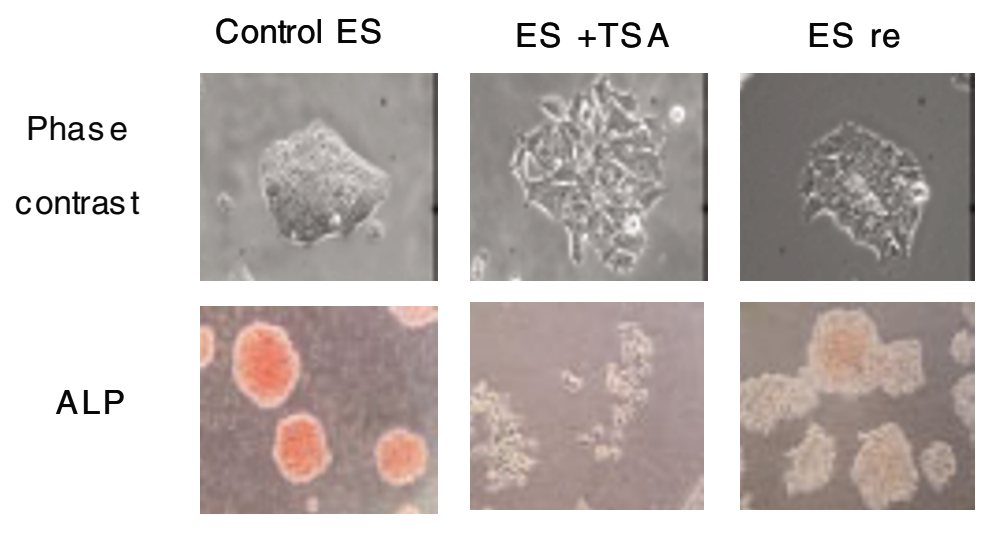

(b)

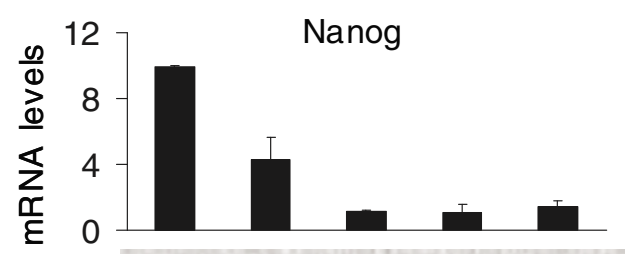

W.B: a-Nanog

TSA (hrs): $\quad \begin{array}{lllll}0 & 2 & 4 & 6 & 12\end{array}$

(c)

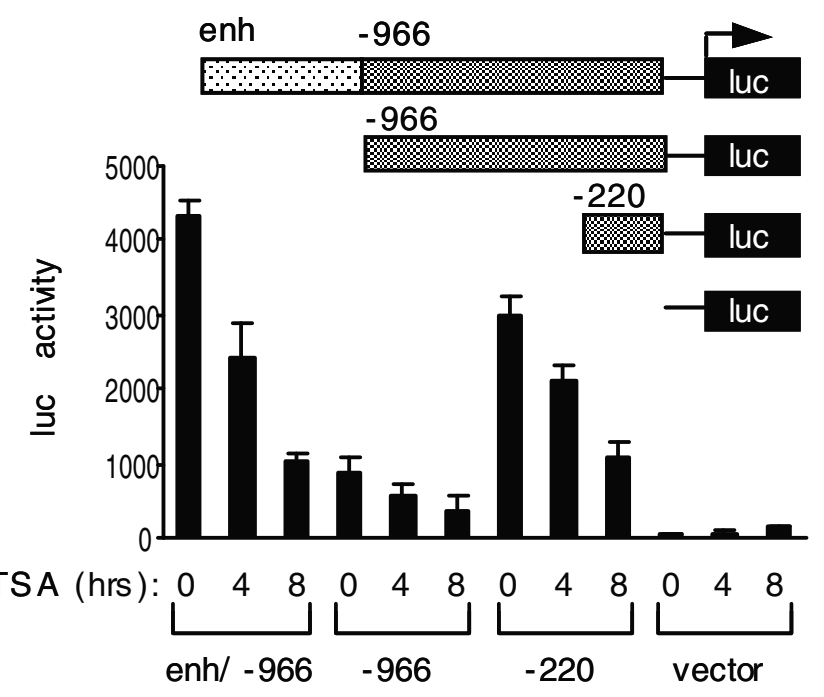

Figure I

Cell morphology and Nanog expression after TSA treatment. (a) ES cells were treated with $50 \mathrm{nM}$ TSA for $12 \mathrm{~h}$ and then released from TSA for an additional $12 \mathrm{~h}$. Cell morphology and ALP staining of the three states (ES control, ES+TSA and ES re are shown. (b) Nanog mRNA and protein levels after 2, 4, 6 and $12 \mathrm{~h}$ of TSA treatment $(50 \mathrm{nM})$. (c) Luc activity of Nanog promoter/enhancer domains. ES cells were transfected with the indicated fusions of Nanog promoter/enhancer fragments to the luciferase reporter gene. Transfected cells were treated with TSA for 0,4 and $8 \mathrm{~h}$. 
transcription start site and containing a Nanog auto-regulatory site [28], is fused to the -966 promoter (Figure 1c, enh/966), it produces a stronger element that is more robustly repressed by TSA than either of the two promoter fragments (Figure 1c). These findings suggest that loss of Nanog expression after TSA treatment is due to transcriptional repression. Moreover, it appears that the effect is mediated by both the proximal promoter, which harbors a composite Oct-4/Sox2 binding site known to regulate Nanog expression [29,30], and the distal enhancer where Nanog binding sites reside [28].

\section{Microarray analysis of the global TSA effects}

The observed morphological effects of TSA and Nanog repression might be indicative of a global and rapid assault on the self-renewal capacity of ES cells, with possibly a simultaneous launch of differentiation. To test this idea, we performed Affymetrix microarray analysis using RNA samples isolated after TSA treatment of ES cells for $6 \mathrm{~h}$ to gauge early events and $12 \mathrm{~h}$ to test putative secondary effects. The data show extensive changes in the ES transcriptome (Additional data file 2), suggesting that a large fraction of the genome was transcriptionally reprogrammed. Of the differentially expressed genes in TSA-treated compared to control ES cells, 792 genes were down-regulated and 1,376 up-regulated at the 2-fold change cut-off value (Additional data file 2). The gene chip data were validated by real time RT-PCR for 20 selected genes (Figure $\mathrm{S}_{3}$ in Additional data file 1).

A selection of up- and down-regulated genes is presented in Table 1 . The category of down-regulated genes contains those encoding important regulators of pluripotency, including Nanog, Sall4, Klf4, Sox2 and Oct4, and other genes typical of the undifferentiated state, such as Rex1/Zfp42, FoxD3, Gdf3, Nrob1, Eras, Rif1, Tbx3 and Esrrb [2]. It also contains genes encoding a group of chromatin and transcription regulators, such as the histone acetyltransferase $\mathrm{PCAF}$, the $\mathrm{H}_{3} \mathrm{~K} 9$ methyl transferase Suv39, the $\mathrm{H}_{3} \mathrm{~K} 9$ demethylases Jmjd1a and Jmjd2c, the $\mathrm{H}_{3} \mathrm{~K} 27$ demethylase Utx, the Polycomb factors Bmi1, Cbx5, Suz12 and Eed (Table 1) and the transforming growth factor- $\beta$ /activin signaling pathway members Inhbb, Gdf3 and Lefty2. Among the early and strongly TSAsupressed genes are Sall1, Gli2 and Klf2, which have not been previously associated with regulation of pluripotency and may be novel candidates.

In the category of up-regulated transcripts, we detected: genes of the neural lineage, such as Hoxa1, Hoxb13, Nnat, and $M b p$; genes of the hematopoietic lineage, for example, $M l f 1$; vascular and neuronal differentiation related genes like $P d g f r \beta$; a group of genes encoding histones, including the differentiation-specific histone Hifo; and genes encoding the connective tissue growth factor Ctgf and the endothelial-specific receptor Edg3. In addition, TSA activates the immediateearly response genes Egr1, Fos and JunB, which have been associated with cell proliferation, differentiation, transformation and apoptosis.
To narrow down the genes under study, we focused on the most significant changes and chose to analyze genes with expression changes equal to or greater than four-fold. Using this gene list we performed a hierarchical clustering in order to uncover genes that respond similarly to TSA treatment, pointing to a possible functional interconnection (Figure 2a; Figure $\mathrm{S}_{4}$ in Additional data file 1). This analysis showed the existence of two major clusters of down-regulated (cluster 1) and up-regulated (cluster 2) genes and unveiled a further division of each cluster into two subclusters (Additional data file 3). Subclusters $1 \mathrm{~b}$ (117 transcripts) and 2a (111 transcripts) show major changes at $6 \mathrm{~h}$ whereas subclusters 1a (6o transcripts) and 2b (112 transcripts) do so at $12 \mathrm{~h}$. To functionally categorize the gene clusters and subclusters, we used the Database for Annotation, Visualization, and Integrated Discovery (DAVID) [31] to obtain Gene Ontology annotations for the category of 'biological process' (Table 2). Down-regulated transcripts (subclusters $1 \mathrm{a}$ and $1 \mathrm{~b}$ ) contain genes that fall in the categories of metabolism (Cbr3, Tdh, Enpp3, Cacna1a, Cul1), development/morphogenesis (Nanog, Nrob1, Sall1, Gli2, Lefty1, Lefty2) and growth (Gdf3, Gja1, Socs2, Inhbb). In addition, genes from subcluster $1 \mathrm{~b}$ fall in the category of transcription (Tcfap4, Gtf2I, Ubtf, Suv39h1). Up-regulated genes from the early-induced subcluster $2 \mathrm{a}$ participate in neural system development (Sema4f, Hoxa1, Stxbp1), whereas subcluster $2 \mathrm{~b}$ (induced after $12 \mathrm{~h}$ ) contains genes that take part in angiogenesis and hemopoiesis. Additionally, subcluster 2 a members participate in cell organization/biogenesis (CenpJ, Tubb2a, Sept4) and intracellular signaling (Edg3, Rnd1, Mknk2), while subcluster 2b members have been implicated in metabolism (Hsdl2, Tgm2, Pygl), chromosome organization, that is, nucleosome and chromatin assembly/disassembly, (H1h2bf, H1h2bc, H12bp, H2h2be, $\left.H_{1} f x\right)$ and antigen processing ( $\left.H_{2}-T_{3}, H_{2}-K_{1}, C D_{74}\right)$.

An overview of the various gene function categories is shown as pie charts for clusters 1 and 2 in Figure 2b. Comparison of the pie chart representations between up- and down-regulated genes reveals some interesting differences. For example, regulators of cell cycle, cell growth and transcription are represented in the cluster of down-regulated genes, suggesting a strong effect of TSA treatment on the self-renewal machinery. On the other hand, signaling and adhesion molecules become evident in the pie chart of induced genes, indicating the appearance of new response mechanisms to environmental cues. A full list of genes from each subcluster and the corresponding biological process annotations are included in Additional data files 3-7.

\section{Histone deacetylase inhibition effects resemble gene expression changes appearing during embryoid body differentiation}

To examine how gene expression modulation caused by TSA corresponds to changes taking place during the 'natural' in vitro differentiation process, we placed ES cells in hanging drops to form embryoid bodies (EBs) and allowed them to dif- 
Table I

\begin{tabular}{|c|c|c|c|c|}
\hline Gene symbol & $\begin{array}{c}\text { Fold change } 0 \text { to } 6 \\
\text { hrs TSA }\end{array}$ & $\begin{array}{c}\text { Fold change } 0 \text { to } 12 \\
\text { hrs TSA }\end{array}$ & F-test_p-value & Function (biological process) \\
\hline $\operatorname{lnhbb}$ & -11.91 & -11.93 & $2.33 \mathrm{E}-08$ & Growth \\
\hline Sall & -10.95 & -16.09 & I.06E-05 & System development \\
\hline Nanog & -9.87 & -15.24 & 2.27E-05 & Stem cell division \\
\hline Gdß3 & -8.11 & -12.56 & $9.83 \mathrm{E}-07$ & Growth \\
\hline Lefty2 & -5.7 & -16.58 & $6.87 \mathrm{E}-06$ & Development \\
\hline Gli2 & -5.61 & -8.38 & 4.34E-08 & Regulation of transcription, DNA-dependent \\
\hline KIf2 & -4.73 & -10.39 & $4.48 \mathrm{E}-08$ & Positive regulation of transcription \\
\hline Zfp $42 / \operatorname{Rex}$ & -4.62 & -5.00 & I.0IE-05 & Regulation of transcription, DNA-dependent \\
\hline Foxd3 & -4.59 & -4.66 & $3.74 \mathrm{E}-05$ & Regulation of transcription, DNA-dependent \\
\hline Tbx3 & -4.46 & -6.10 & $9.29 \mathrm{E}-05$ & Development, cell aging, negative regulation of transcription \\
\hline Eras & -4.22 & -5.94 & 3.IIE-06 & Small GTPase mediated signal transduction \\
\hline $\mathrm{NrObl}$ & -4.11 & -13.39 & I.70E-06 & Negative regulation of transcription \\
\hline Rifl & -4.03 & -3.82 & I.54E-04 & Response to stress, chromosome maintenance \\
\hline Leftyl & -3.66 & -9.11 & $1.13 \mathrm{E}-06$ & Development, cell growth \\
\hline Suv39hI & -3.50 & -4.87 & $2.38 \mathrm{E}-06$ & Chromatin assembly or disassembly, chromatin modification \\
\hline Sall4 & -3.47 & -3.34 & 2.47E-03 & Stem cell pluripotency \\
\hline Utx & -3.61 & -2.81 & $1.68 \mathrm{E}-04$ & Chromatin modification \\
\hline Pcaf & -3.29 & -5.15 & $3.79 \mathrm{E}-05$ & Regulation of transcription, DNA-dependent \\
\hline Bmil & -3.39 & -1.80 & $2.39 \mathrm{E}-06$ & Chromatin modification, somatic stem cell division, development \\
\hline KIf4 & -3.02 & -4.09 & I.59E-06 & Regulation of transcription, DNA-dependent \\
\hline Fgf4 & -2.95 & -3.47 & $2.23 \mathrm{E}-06$ & Stem cell maintenance, regulation of cell cycle \\
\hline Zic3 & -2.87 & -3.28 & $2.38 \mathrm{E}-05$ & Regulation of transcription \\
\hline Esrrb & -2.64 & -4.26 & $2.96 \mathrm{E}-04$ & Regulation of transcription, DNA-dependent \\
\hline Sox2 & -2.43 & -1.63 & 2.03E-04 & Cell fate specification, regulation of transcription, DNA-dependent \\
\hline Jmjd la & -2.20 & -2.94 & 8.14E-08 & Chromatin modification \\
\hline Suz 12 & -2.10 & -1.87 & $1.58 \mathrm{E}-03$ & Chromatin modification \\
\hline Jmjd2c & -2.20 & -2.27 & $2.28 \mathrm{E}-04$ & Chromatin modification \\
\hline$T c l l$ & -1.85 & -3.13 & I.09E-04 & Regulation of transcription \\
\hline Eed & -1.80 & -2.05 & 2.37E-05 & Imprinting \\
\hline Cbx5 & -1.42 & -2.21 & I.76E-03 & Chromatin assembly or disassembly \\
\hline Pou5fl & -1.09 & -1.74 & $6.04 \mathrm{E}-04$ & Stem cell maintenance \\
\hline Egrl & 28.37 & 40.75 & $1.53 \mathrm{E}-06$ & Regulation of transcription, DNA-dependent \\
\hline HIfO & 13.39 & 22.33 & 4.45E-06 & Nucleosome assembly \\
\hline Hist /h/c & 12.34 & 17.88 & I.0IE-03 & Nucleosome assembly, chromosome organization and biogenesis \\
\hline Pdgfrb & 9.78 & 10.77 & $3.98 \mathrm{E}-06$ & Protein tyrosine kinase signaling pathway \\
\hline Fos & 8.02 & 11.35 & $9.00 \mathrm{E}-07$ & Regulation of cell cycle, regulation of transcription, neurogenesis \\
\hline Ndrg4 & 7.87 & 8.15 & $9.85 \mathrm{E}-06$ & Cell differentiation, development \\
\hline Hist3h2a & 5.98 & 11.17 & 7.97E-04 & Nucleosome, chromosome \\
\hline Cregl & 4.65 & 5.32 & 2.84E-06 & Regulation of transcription, DNA-dependent \\
\hline Ttlll & 4.47 & 5.13 & 7.84E-06 & Protein modification \\
\hline Nnat & 4.05 & 8.37 & I.04E-03 & Development \\
\hline Hoxal & 4.05 & 5.34 & 8.6IE-06 & Anterior/posterior pattern formation, hindbrain development \\
\hline Edg3 & 3.88 & 4.82 & $1.53 \mathrm{E}-04$ & G-protein signaling, positive regulation of cell proliferation \\
\hline Cacnalb & 3.83 & 7.21 & $8.76 \mathrm{E}-04$ & Neurotransmitter secretion, regulation of heart contraction \\
\hline
\end{tabular}


Table I (Continued)

Functional annotation (biological process) and mRNA fold change of selected TSA (6 and I 2 h) down- and up-regulated genes

\begin{tabular}{lccll}
\hline Idb2 & 3.49 & 7.12 & $3.42 \mathrm{E}-04$ & Development, heart development, lymph gland development \\
Hoxb/3 & 3.33 & 4.45 & $6.74 \mathrm{E}-06$ & Pattern specification, organogenesis, regulation of growth \\
Cacnalh & 3.15 & 5.50 & $1.45 \mathrm{E}-05$ & Calcium ion transport \\
Cbx4 & 3.14 & 4.85 & $5.13 \mathrm{E}-05$ & Chromatin assembly or disassembly, chromatin modification \\
Sirt7 & 2.69 & 2.68 & $1.05 \mathrm{E}-04$ & Chromatin silencing, regulation of transcription, DNA-dependent \\
MIfI & 2.29 & 12.44 & $6.88 \mathrm{E}-05$ & Cell differentiation \\
Ctgf & 2.12 & 9.88 & $6.80 \mathrm{E}-04$ & Ossification, angiogenesis, regulation of cell growth, cell adhesion \\
Cbx2 & $1.8 \mathrm{I}$ & 2.00 & $6.16 \mathrm{E}-05$ & Chromatin assembly or disassembly, chromatin modification \\
Wifl & $1.4 \mathrm{I}$ & 6.33 & $2.38 \mathrm{E}-06$ & Negative regulation of Wnt receptor signaling pathway \\
\end{tabular}

ferentiate without LIF. We then analyzed the mRNA levels of six genes from Table 1 that are strongly affected, negatively or positively, by TSA. These genes were those encoding Nanog, the spalt homologue Sall1, the orphan nuclear receptor Nrob1, the vascular and neuronal differentiation related receptor Pdgfr $\beta$, and the hematopoietic lineage switch gene Mlf1 and the homeotic Hoxa1 gene. Figure 3a shows that TSA causes a very rapid repression of Nanog, Nrob1 and Sall1, a rapid but more gradual induction of Pdgfr $\beta$ and Hoxa1, and a late increase of Mlf1 mRNA levels. (a)

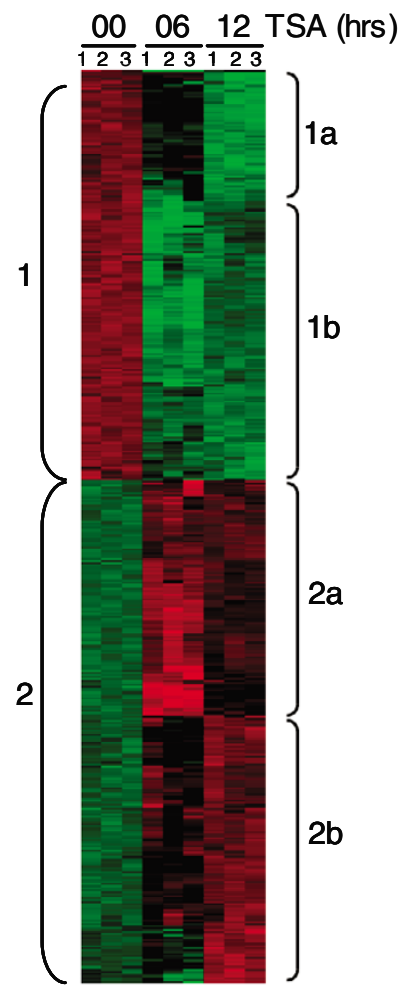

(b)

Up regulated genes

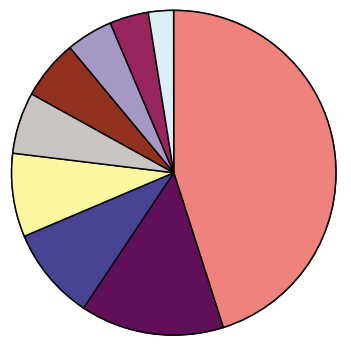

metabolism

development

diffe rentiation

proliferation

adhesion

chromosome organization

antigen processing

$\square$ signaling

transport

Dow $n$ regulated genes

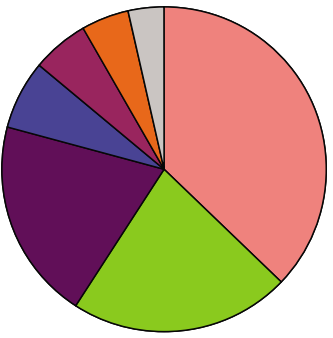

metabolism

development

cell differentiation

cell proliferation

cell cycle

trans cription

growth

\section{Figure 2}

Gene expression changes after TSA treatment and functional annotation of affected genes. (a) Hierarchical cluster analysis of the TSA-induced transcriptome. The numbers I, 2, and 3 at the top represent three biological replicates of the experiment. Brackets on the left mark the two major clusters of down-regulates (cluster I) and up-regulated (cluster 2) genes. Brackets on the right mark the subclusters of the four different expression profiles observed, that is, down-regulation after $12 \mathrm{~h}$ of TSA treatment (subcluster la) or after $6 \mathrm{~h}$ (subcluster Ib), and up-regulation after $6 \mathrm{~h}$ (subcluster 2a) or $12 \mathrm{~h}$ (subcluster $2 \mathrm{~b}$ ). (b) Pie charts representing the functional annotation of up- or down-regulated genes. Transcripts differentially expressed by $\geq$ 4 -fold after 6 or $12 \mathrm{~h}$ of TSA treatment were used for all the above experiments. 
Table 2

\begin{tabular}{|c|c|c|}
\hline Subcluster & Genes & Function \\
\hline \multirow[t]{6}{*}{ la } & LeftyI, Lefty2, NrObI, Mcf2, Notch4, & Metabolism \\
\hline & Foxh I, Ubtf, Gtf2i, Tdh, Uppl, Fkbp9, & Development: embryonic, tube \\
\hline & Enpp3, Socs2, Cacna I a, Pycard, Enah, & Morphogenesis \\
\hline & Lefl, Esrrb, Rnfl 25, Ddc, Bcat I, Dpp4, & Pattern specification \\
\hline & Ptpmtl, Ctbp2, Pml, Ptbp2, Hnrpa2bl & Cell differentiation \\
\hline & & Growth \\
\hline \multirow[t]{7}{*}{ Ib } & Nanog, Tbx3, Sall I, Gdf3, Klf3, Klf4, & Metabolism \\
\hline & Zic3, Zic5, FoxD3, Gli2, Gjal, Otx2, & Transcription \\
\hline & $\begin{array}{l}\text { Zbtb7a, Nsdl, Arid la, NFIb, Pitx2, Rarg, Suv39HI, Cull, Ppap2b, } \\
\text { Pdgfc, Tns3, }\end{array}$ & Development: embryonic, organ, tube \\
\hline & $\begin{array}{l}\text { Inhbb, Fn I, Tcfap4, Nr5a2, MIIT6, Irf2bp2, Pcaf, Zfp42, ZmyndII, } \\
\text { Ncorl, }\end{array}$ & Morphogenesis: embryonic, organ, tube \\
\hline & MIITI0, Tgif, Trps I, Empl, Pkd2, Spry2, & Cell proliferation \\
\hline & Gjb3, Fgf4, Vegfc, HsdI 7BII, Cbr3, & Growth \\
\hline & Fbxol5, Dusp27, Frrs I, Cdk6, Epb4.9, Irak3, Spry4, Manba, Folrl & \\
\hline \multirow[t]{3}{*}{$2 a$} & $\begin{array}{l}\text { Sema4f, Mbp, Cnp, Stxbpl, Hoxal, Fos, Farp2, Sept4, Krtl-I8, HIfO, } \\
\text { Tubb2a, }\end{array}$ & Cell organization and biogenesis \\
\hline & $\begin{array}{l}\text { Dnajc1 2, Cenpj, Spire I, Pappa2, Sh2b2, Tax lbp3, Rnd I, Arhgap29, } \\
\text { Edg3, Mknk2, Errfl, Rap40b, Pdgfrb }\end{array}$ & $\begin{array}{l}\text { System development: nervous system development; neurogenesis; } \\
\text { cell development }\end{array}$ \\
\hline & & Intracellular signaling \\
\hline \multirow[t]{5}{*}{$2 b$} & Id2, Id4, WifI, Hoxb/3, Prkar Ib, Prkar2b, & Metabolism \\
\hline & $\begin{array}{l}\text { Zfp 36, Cd74, Thyl, Serpine I, Dhcr7, Pdlim7, Ctgf, MlfI, Lgals I, Kif3a, } \\
\text { Irf8, Hsdl2, HIh2bf, HIh2bp, HIh2bc, H2h3cl, Junb, Cbx4, Hspala, } \\
\text { Hspalb, Hspa2, Acaa lb, HIfx, Psmb9, H2-T3, H2-KI, Hist Ih2bn }\end{array}$ & $\begin{array}{l}\text { Development: organ development/morphogenesis; vasculature } \\
\text { development; angiogenesis; hemopoiesis/blood vessel development }\end{array}$ \\
\hline & & Cell differentiation \\
\hline & & Chromosome organization \\
\hline & & Immune response \\
\hline
\end{tabular}

During embryoid body differentiation, suppression or induction of individual genes takes place in distinct time frames. To compare the TSA effect with EB differentiation, days 4 and 8 were chosen as the most indicative even though gene expression changes were observed earlier (EBs days 2 and 3). Nanog, Nrob1 and Sall1 were also found to be repressed during EB formation whereas Pdgfr $\beta$, Mlf1 and Hoxa1 genes were activated. (Figure 3b). Therefore, the expression of these genes in embryoid bodies is regulated in the same direction as after TSA treatment, albeit at much slower paces (Figure $3 \mathrm{~b}$ ). This was true for the majority of genes checked so far.

\section{The effect of TSA is partially reversible}

We next asked if the differentiation imposed by TSA is reversible. To answer this question, ES cells were treated with TSA for $12 \mathrm{~h}$ and then cultured for an additional 6 and $12 \mathrm{~h}$ without TSA (ES re). We observed that the morphological changes induced by TSA were gradually reversed with the emergence of compact colonies (approximately 70\% of the control), which are indicative of the undifferentiated state (Figure 1a, ES re). These colonies stain weakly for ALP in their center (Figure 1a). RT-PCR analysis demonstrated that the expression of Nanog, Mlf1, Hoxa1 and Pdgfr $\beta$ was fully reversed to pre-treatment, undifferentiated ES cell levels (Figure 3a). In contrast, the mRNA levels of Nrob1 and Sall1 did not recover fully. In agreement with the reduction of Nanog mRNA, FACS analysis showed that the population of cells expressing Nanog above control antibody levels was reduced by TSA and then recovered upon release from TSA treatment (Figure $\mathrm{S}_{5}$ in Additional data file 1). Further analysis of three well characterized pluripotency factors, Oct4, Sox2 and Zfp42/Rex1, revealed that the mRNA levels of Oct4 and Sox2 but not of Zfp42/Rex1 were restored after TSA removal (Figure S2 in Additional data file 1). In conclusion, although the morphological changes that are caused by TSA treatment are largely reversed, expression of individual genes can undergo either fully or partially reversible alterations. The partial return to the ES cell phenotype suggests that histone deacetylase inhibition alone does not appear to fully commit ES cells to differentiation.

In order to examine the competence of the 'ES re' cells to contribute to the three germ layers, we placed them in hanging drops and observed that they formed EBs of normal morphology. We then checked for expression of markers of the three germ layers, endoderm (Sox17), mesoderm (Brach- 
$\begin{array}{lll}\text { (a) } & \text { (b) } & \text { EB }\end{array}$

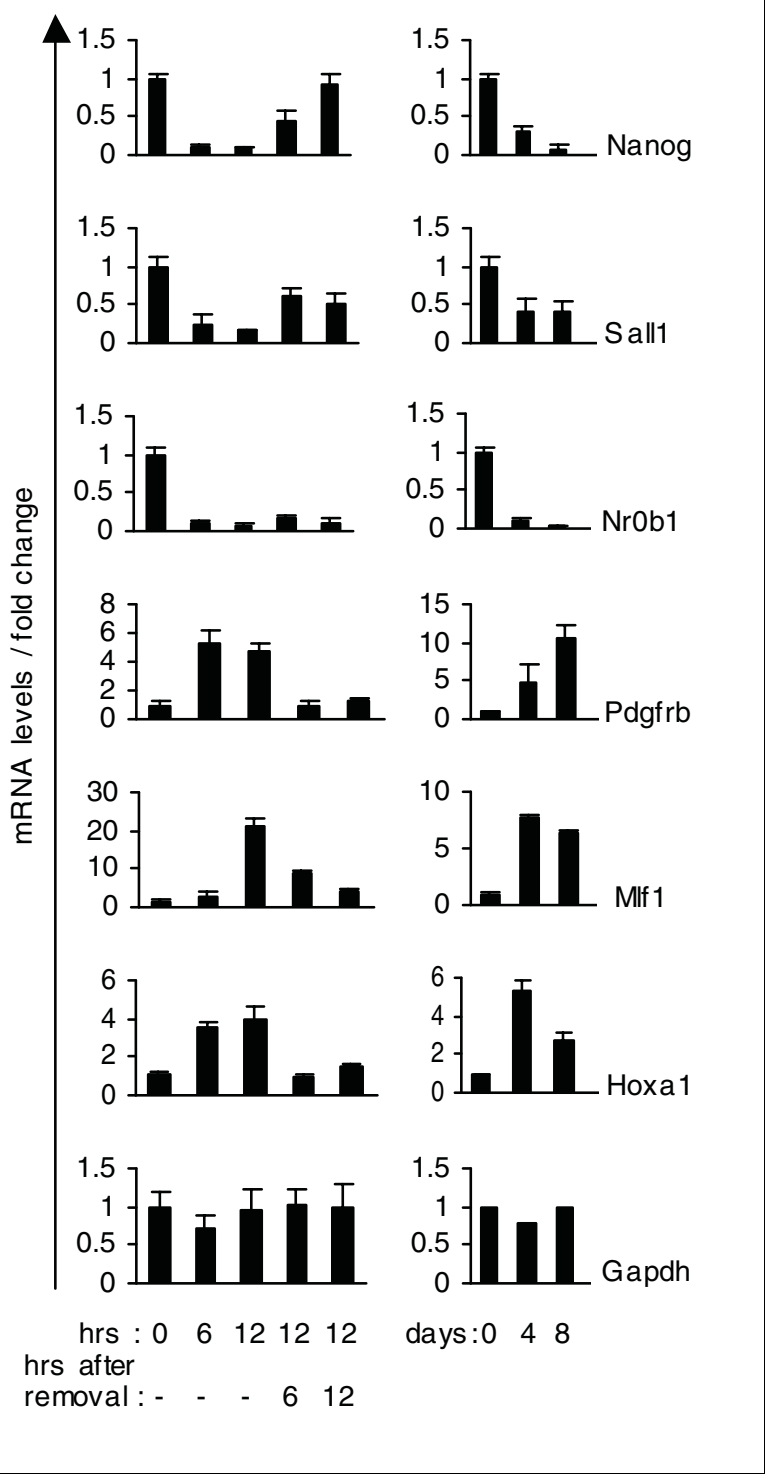

Figure 3

Expression patterns of selected genes in TSA-treated ES cells and EBs. mRNA levels of Nanog, Sall I, NrOb I, Pdgfrb I, Mlfl and Hoxal in: (a) ES cells treated with $50 \mathrm{nM}$ TSA for 6 and $12 \mathrm{~h}$. After $12 \mathrm{~h}$ of treatment, TSA was removed and cells were cultivated for an additional period of 6 and 12 h. (b) EBs 0, 4 and 8 days old. Control mRNA levels ( 0 h TSA/0 days EBs) were set to I and normalized with glyceraldehyde phosphate dehydrogenase. mRNA levels were analyzed with real-time PCR.

yury) and ectoderm (Mash1). As shown in Figure 4, Sox 17 and Mash1 followed the same expression patterns as in wildtype cells whereas Brachyury was up-regulated one day later than in wild-type cells. These results show that 'ES re' cells are still capable of acquiring either one of the three cell fates.

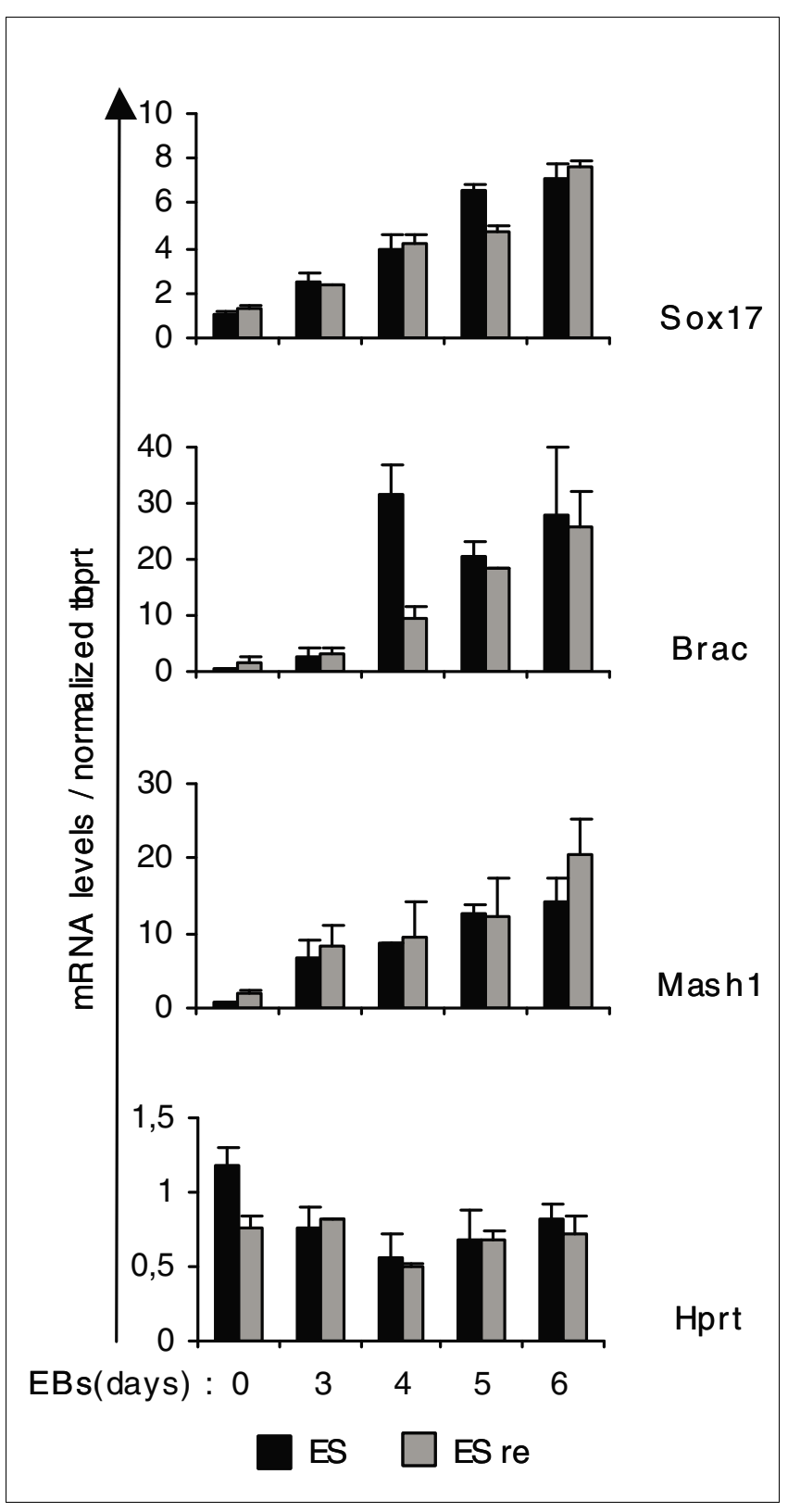

Figure 4

mRNA levels of Sox I 7, Brac and Mash / during EB formation of control and released ES cells (ES re). Control and released ES cells grown at clonal density were placed in hanging drops to form EBs. mRNA levels of the indicated genes were measured using real time RT-PCR analysis and were normalized to Hprt.

\section{Histone modification changes correlate with gene expression reprogramming}

To gain insight into the molecular mechanisms whereby TSA triggers stem cell differentiation, we analyzed the dynamics of histone $\mathrm{H}_{3}$ modifications after TSA treatment and compared them to changes taking place during EB formation. In both cases, we observed an increase in the global amounts of two activatory modifications, $\mathrm{H}_{3}$ acetylation and $\mathrm{K} 4$ trimethylation and a decrease in repressive K27 trimethylation (Figure 


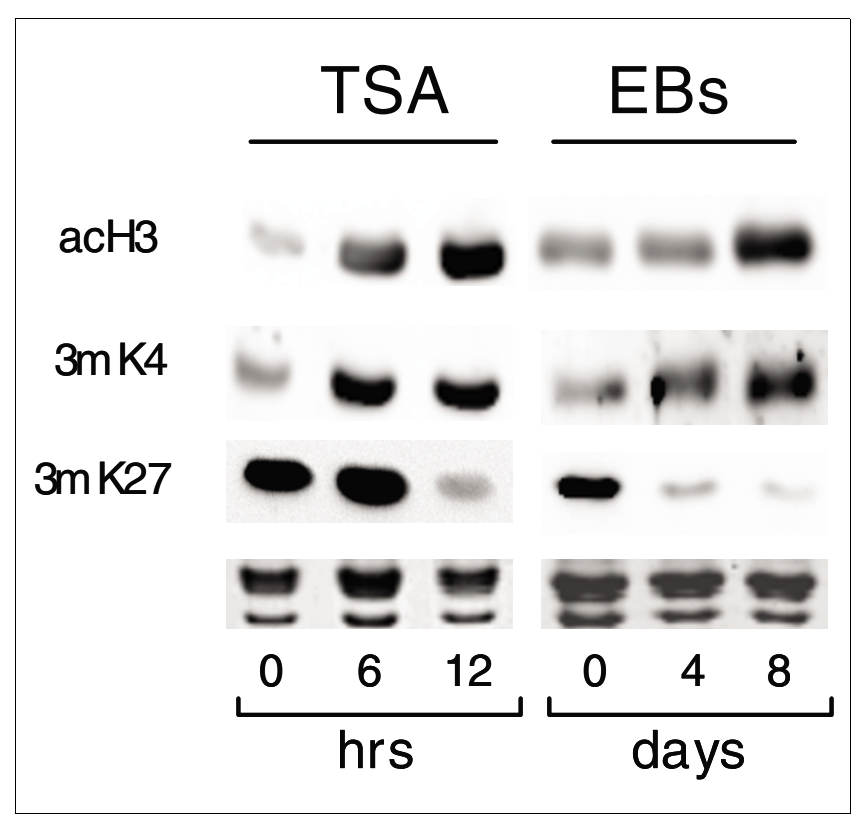

Figure 5

Analysis of bulk histone modifications in TSA-treated ES cells and EBs. Global levels of histone $\mathrm{H} 3$ acetylation $(\mathrm{acH} 3)$, and lysine $4(3 \mathrm{mK} 4)$ and lysine 27 (3mK27) trimethylation, employing immunoblotting with specific antibodies. Equal loading was controlled with Coomassie blue staining.

5). These results show that TSA treatment instigates a global enhancement of activation-linked epigenetic marks that also appears during the natural ES cell differentiation process.

However, analysis of individual genes using ChIP assays uncovered a complex, gene-specific pattern of histone modifications (Figure 5). In this experiment, we first examined the histone modifications on the promoters of three genes that were up-regulated by TSA, namely $P d g f r \beta, M l f 1$ and Hoxa1 (Figure $3 a$ ). During activation of $P d g f r \beta$ and $M l f 1$ by TSA, we detected an increase in $\mathrm{H}_{3}$ acetylation and $\mathrm{H}_{3} \mathrm{~K}_{4}$ trimethylation and a decrease in $\mathrm{H}_{3} \mathrm{~K} 27$ trimethylation (Figure 6a). Analysis during EB formation (Figure 6b) gave similar results. In contrast, we found that the neural lineage gene Hoxa1 had significant concurrent activatory (K4) and suppressive (K27) methylations in the undifferentiated state (in agreement with the bivalent structure model [20]). Upon activation by TSA, we observed a reduction in K27 trimethylation levels and maintenance of $\mathrm{K}_{4}$ trimethylation and $\mathrm{H}_{3}$ acetylation levels. Thus, activation of Hoxa1 expression after TSA treatment relies on loss of suppressive modifications. Hoxa1 expression during EB differentiation is correlated with a transient increase in $\mathrm{H}_{3}$ acetylation, matching the Hoxa1 maximal activation (Figure 3a), and a transient decrease in K27 trimethylation (Figure 6b). In contrast to this finding, another study [32] has reported that TSA-induced activation of Hoxa1 is not correlated with a drop in K27 trimethylation. However, in that case, ChIP analysis was performed on a retinoic acid-regulated enhancer at the 3 ' end of the gene as opposed to our analysis, which is based on the 5 ' promoter region, proximal to the transcriptional start site.

ChIP analysis was also performed for genes down-regulated by TSA treatment. Along with Nanog mRNA repression, we detected a gradual decrease of $\mathrm{H}_{3}$ acetylation and an abrupt drop in $\mathrm{H}_{3} \mathrm{~K}_{4}$ trimethylation of its promoter without an increase in the repressive $\mathrm{H}_{3} \mathrm{~K} 27$ trimethylation (Figure 6a). During EB differentiation, Nanog inactivation similarly correlates with a decrease in both $\mathrm{H}_{3}$ acetylation and $\mathrm{H}_{3} \mathrm{~K}_{4}$ trimethylation, but in this case gene suppression is also accompanied by an increase in $\mathrm{H}_{3} \mathrm{~K} 27$ trimethylation (Figure 6b). Unlike Nanog, repression of Nrob1 was accompanied by a robust increase in $\mathrm{H}_{3} \mathrm{~K} 27$ trimethylation, and no significant decrease of either acetylation or $\mathrm{H}_{3} \mathrm{~K}_{4}$ trimethylation (Figure 6a). In EBs, $\mathrm{H}_{3} \mathrm{~K} 27$ trimethylation was also increased but both activatory modifications were reduced. Finally, the Sall1 promoter represented an intermediate situation of repression, connected to a strong decrease in acetylation, a decrease in $\mathrm{H}_{3} \mathrm{~K}_{4}$ trimethylation and a rise in $\mathrm{H}_{3} \mathrm{~K}_{2} 7$ trimethylation (Figure 6a). Similar changes accompany Sall1 deactivation during EB differentiation.

Trimethylation of K27 is catalyzed by Enhancer of Zeste 2 (Ezh2), a methyl-transferase component of the PRC2 complex. Employing ChIP assays, we confirmed the recruitment of Ezh2 on Nanog, Sall1 and Nrob1 promoters (Figure 7a), in agreement with the appearance of K27 trimethylation during suppression either by TSA or in EBs (Figure 6a,b). Gene activation or repression of all six genes in both TSA-treated ES cells and EBs correlates with a respective increase or decrease in promoter-bound RNA polymerase II (Figure 6a,b). These results indicate that the observed chromatin modifications correlate well with the expected recruitment of transcriptional regulators and enzymes to the corresponding gene promoters.

Correlating ChIP data with changes in mRNA levels, it appears that $\mathrm{H}_{3} \mathrm{~K} 27$ trimethylation might predispose individual genes for stable repression. For example, Sall1 and Nrob1, which show an increase in $\mathrm{H}_{3} \mathrm{~K} 27$ trimethylation following addition of TSA (Figure 6a), do not regain full expression after release from TSA (Figure 3a). Nanog, on the other hand, which is not marked by $\mathrm{H}_{3} \mathrm{~K} 27$ trimethylation when repressed, regains full expression following TSA release. To further strengthen this idea, we prepared chromatin samples from cells treated with TSA for $12 \mathrm{~h}$ and then released for 6 and $12 \mathrm{~h}$. ChIP analysis shows that $\mathrm{H}_{3} \mathrm{~K} 27$ trimethylation induced by TSA is maintained on the Nrob1 promoter and, partially, on the Sall1 promoter even after TSA removal (Figure $7 \mathrm{~b}$ ), in agreement with the irreversible repression of the two genes (Figure 3a). Collectively, by analyzing six different genes during TSA treatment and EB formation, we have encountered similar but gene-specific combinations of promoter chromatin modifications that correlate with expression state. 


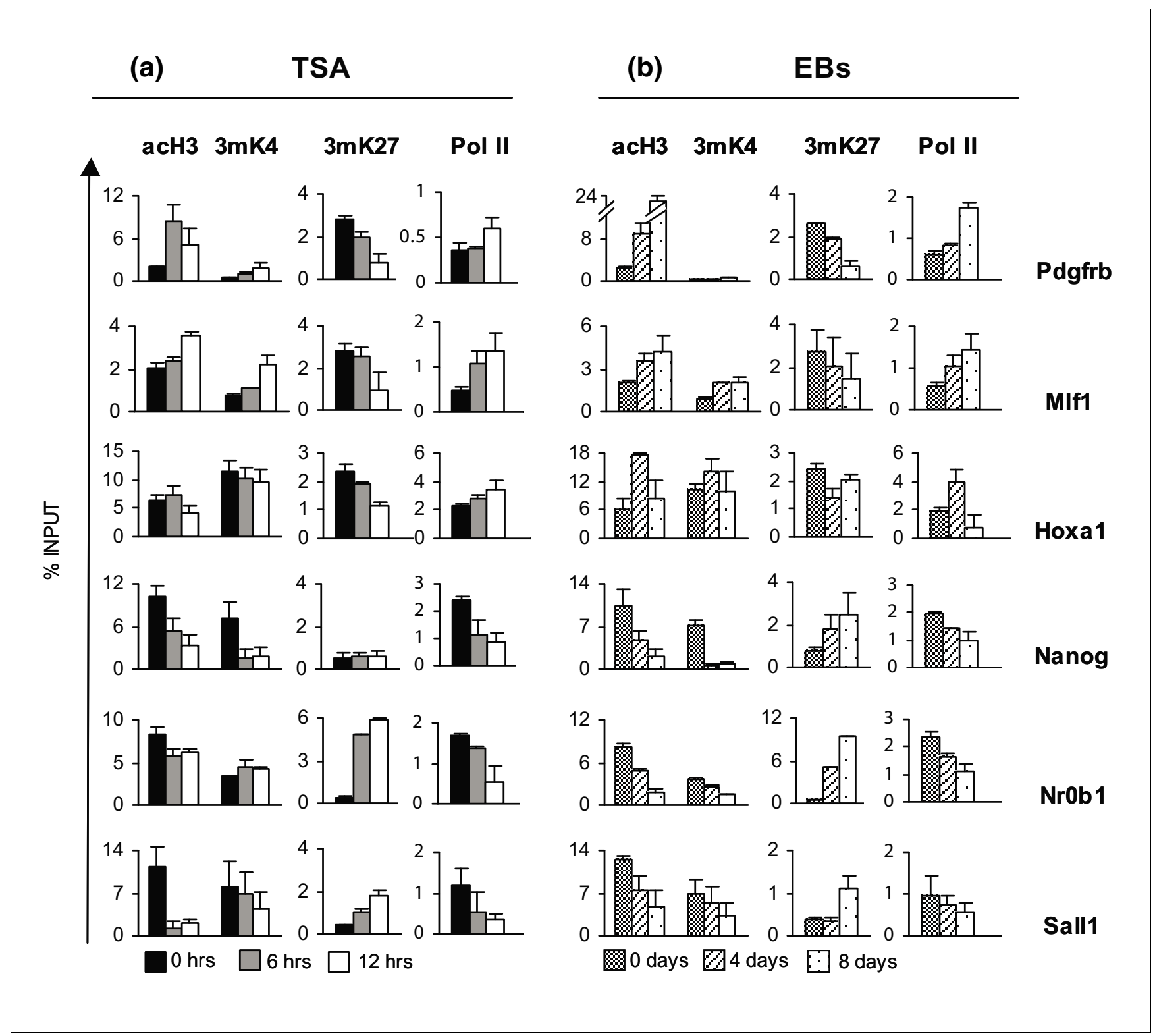

\section{Figure 6}

Histone modification changes and RNA polymerase (Pol) II levels on gene promoters during TSA treatment and EB formation. Histone modifications ( $\mathrm{H} 3$ acetylation $(\mathrm{acH} 3)$, and lysine $4(3 \mathrm{mK} 4)$ and lysine 27 (3mK27) trimethylation) and Pol II levels on the promoters of (a) activated genes (Pdgfr $\beta$, Mlfl, Hoxal) and (b) repressed genes (Nanog, NrObl, SallI) during TSA treatment (left) or EB differentiation (right). Modification levels were estimated using ChIP assays. Results are expressed as percent of the input chromatin.

\section{Discussion}

ES cells can differentiate along various pathways and this process is linked to their unusually open chromatin structure [24]. In this report, we have undertaken a transcriptomic approach in order to analyze how histone deacetylase inhibition affects the self-renewal activity or differentiation of mouse ES cells. In parallel, we have examined histone modification changes that correlate with transcriptional reprogramming.
Gene expression profiling following histone deacetylase inhibition in ES cells revealed two major gene clusters: genes highly expressed in undifferentiated cells that are suppressed by TSA and genes not expressed in ES cells that are activated by TSA. Expression levels of these genes change in an opposite way. This may reflect a cross-regulation between genes of the two clusters, or the existence of common regulators that modulate the simultaneous repression or induction of selective targets. The second possibility seems valid in the light of the discovery that binding of Nanog/Oct4/Sox2 complexes to 


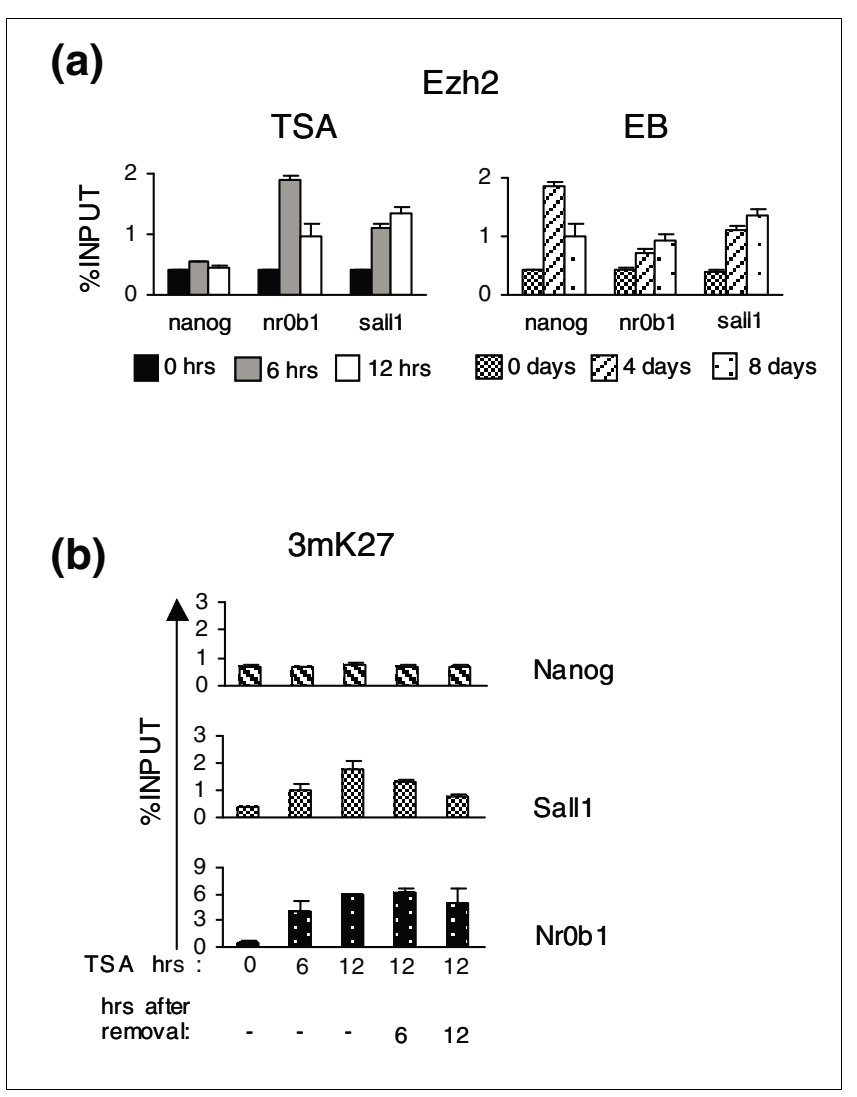

Figure 7

Ezh2 and H3K27 trimethylation levels on the promoters of Nanog, Sall I and $\mathrm{NrOb}$ I. (a) ChIP assays using an anti-Ezh2 antibody on the promoters of Nanog, Sall I and NrObl during TSA treatment (6 and I $2 \mathrm{~h}$ ) and EB formation ( 4 and 8 days). (b) ChIP assays using an anti-3mK27 antibody were performed for the promoters of TSA down-regulated genes Nanog, Sall I and $\mathrm{NrOb} /$ after 6 and $12 \mathrm{~h}$ of TSA treatment and further cultivation without TSA for an additional 6 and $12 \mathrm{~h}$.

promoter regions maintains different gene targets in either active or inactive states [6].

Nanog, among other genes encoding pluripotency factors, is an early and strongly (approximately 15-fold) TSA-suppressed gene. Studying the activity of different Nanog promoter/enhancer regions, we found that this effect is transcriptional and depends on the proximal promoter $(-220$ $\mathrm{kb})$ and the distal enhancer $(-5 \mathrm{~kb})$. Oct4 and Sox2 are known regulators of the Nanog proximal promoter. Since the genes for Oct4 and Sox2 are only weakly repressed, it is unlikely that they are the main mediators of the TSA effect on the Nanog promoter. A fine, site-specific, mutational analysis could clarify the regulatory elements targeted by TSA, as well as the cognate DNA binding factors.

Our microarray analysis indicates that histone deacetylase inhibition induces the exit from the undifferentiated state as revealed by the suppression of most known pluripotency factors (Tables 1 and 2). Therefore, we propose that many other genes in this category, that is, those suppressed by TSA, might also be involved in the regulation of self-renewal. Despite the swift loss of many pluripotency factors, induction of differentiation was not directed to a particular lineage. Instead, we detected up-regulation of various genes associated with neural and mesodermal, but not endodermal, differentiation, indicating that TSA leads cells to an intermediate stage between the undifferentiated and the finally differentiated states.

Histone deacetylase inhibition induces gene expression changes and chromatin modifications that also take place during the 'natural' differentiation process, albeit in a compressed time frame. For example, changes appearing within 12 hours of TSA treatment manifest during an eight-day period of EB differentiation. On a global scale, the TSA effects include increases in the activating modifications histone $\mathrm{H}_{3}$ acetylation and $\mathrm{K}_{4}$ trimethylation and a concomitant loss of the repressive K27 trimethylation. As previous studies have shown that undifferentiated ES cells bear increased activation marks when compared to their differentiated descendants [15], our results suggest that before full commitment to a differentiated phenotype, there might be a window of chromatin 'over-permissiveness' characterized by an increase in activation marks (Figure 5). TSA might facilitate this transient phase, thus accelerating cell differentiation, possibly by reorganizing the chromatin structure [33].

TSA can have different effects depending on the dose and duration of the treatment and the target cell differentiation state. Brief treatment with 300 nM TSA provoked changes in the allelic chromatin conformation of the imprinted U2af1rs1 locus in mouse ES cells but not fibroblasts [34]. In another report [35], the addition of TSA during EB formation resulted in inhibition of differentiation, reflected in persistent ALP staining. It seems, therefore, that when ES cells are disaggregated and put in a specific differentiation milieu, they can not differentiate in the presence of TSA. In line with our results, TSA was shown to promote myocardial differentiation when added to seven-day-old EBs [36] and neuronal differentiation when added to embryonic neural stem cells [37].

Histone deacetylase inhibition is generally considered an inducer of gene activation by increasing $\mathrm{H}_{3}$ acetylation levels. However, examination of the histone modification changes that occur on the promoters of six genes targeted by TSA has revealed complex, gene-specific regulation patterns. Even though TSA inhibits both type I and II, histone deacetylases (HDACs) it can induce a decrease in histone $\mathrm{H}_{3}$ acetylation on the promoters of some (Figure 6), but not all, suppressed genes, as suggested in a previous report [38]. Transcriptional repression induced by TSA might be an indirect effect connected to reduction of PCAF acetyltransferase levels or an increase in Sirt7 deacetylase mRNA levels (Table 1; Additional data file 2). In this scenario, we would have expected suppressed genes to follow slower kinetics compared to acti- 
vated ones. Instead, genes that are strongly suppressed by TSA, such as Nanog, Nrob1 and Sall1, follow very rapid kinetics (Figure S6 in Additional data file 1), arguing for a direct rather than an indirect effect. Moreover, even low doses of TSA can repress Nanog (Figure S1A in Additional data file 1).

The pleiotropy of the TSA effects is obvious when considering the regulation of Nanog by HDAC1. HDAC1 levels on the Nanog promoter increased after TSA treatment (Figure S7 in Additional data file 1), and even though HDAC1 activity is inhibited by TSA, Nanog chromatin is still deacetylated (Figure 6a). In addition, by comparing our data to a microarray analysis of HDAC1 knock out ES cells [39], we found no significant overlap between the two experiments, pointing to the multiplicity of the mammalian deacetylases [38] and their potential non-histone target proteins. We can not exclude the possibility that the acetylation state of non-histone proteins may account for the observed actions of TSA. To explore this possibility, it would be important to examine the acetylation of factors important for the ES differentiation state.

Our study shows that besides acetylation, histone deacetylase inhibition in ES cells dramatically affects methylation of lysines 4 and 27 of histone $\mathrm{H}_{3}$. We have documented for the first time a rapid decrease in $\mathrm{K}_{4}$ and $\mathrm{K} 27$ trimethylation levels. Until recently, it was difficult to explain such phenomena because methylation was considered a stable mark. Based on the recent discovery of novel enzymes that remove trimethylK4 (3mK4) [40,41] and trimethyl-K27 (3mK27) [42,43], we postulate that TSA may modify the recruitment and/or activity of $\mathrm{H}_{3}$ methylation/demethylation complexes. At the moment, it is not clear how this recruitment on specific promoters might be regulated, leaving unclear how genes are selected for repression or activation. Genome-wide analyses have identified target genes for K4 and K27 trimethylations in ES cells $[16,17,22]$. However, apart from the case of Hox genes, the DNA target sites that recruit the mammalian Trithorax and Polycomb complexes remain largely unknown.

We show that the establishment of $\mathrm{H}_{3} \mathrm{~K} 27$ trimethylation correlates well with stable transcriptional reprogramming. For example, Nanog repression, which is reversible in TSAtreated ES cells, is not accompanied by an increase in K27 trimethylation, whereas the opposite occurs in EBs, where the gene is permanently silenced. On the other hand, Nrob1 and Sall1, which are irreversibly repressed by TSA, show increased K27 trimethylation that is maintained even after removal of TSA (Figure 7b). Thus, restoration of Nanog expression may be the reason for the partial reversal of the cells to the undifferentiated state after TSA removal. With regard to this, genome-wide analysis of $\mathrm{H}_{3} \mathrm{~K} 27$ trimethylation maps in correlation with mRNA levels after TSA removal would be very informative. Collectively, histone deacetylase inhibition is able to disrupt stem cell pluripotency and facilitate early differentiation events, although it is not sufficient for commitment to a differentiation fate.

\section{Conclusion}

This work documents comprehensive gene expression changes that are induced by histone deacetylase inhibition in mouse ES cells. Pluripotency regulators, including Nanog, are repressed while differentiation-associated genes related to the neuro-ectodermal and mesodermal lineages are activated. This transcriptional reprogramming is regulated by changes in histone $\mathrm{H}_{3}$ methylation of lysines 4 and 27. Histone deacetylase inhibitors may have applications in stem cell differentiation and in therapies against tumors that express stemness factors.

\section{Materials and methods}

\section{Cell culture, antibodies and chemical reagents}

CGR8 ES cells were cultivated in GMEM (10\% fetal bovine serum, 1,000 units LIF (ESGRO-Chemicon Temecula, CA, USA)). Antibodies were from Upstate (Upstate/Millipore, Billerica, MA, USA) (AcH3, $3 \mathrm{mK}_{4} \mathrm{H}_{3}, 3 \mathrm{mK}_{2} \mathrm{H}_{3}$, Ezh2), Chemicon (Nanog) and Santa Cruz Santa Cruz, CA, USA (His, RNAP II). TSA was from Sigma (Sigma, Saint Louis, MO, USA).

\section{Alkaline phosphatase staining}

CGR8 cells were fixed with $100 \%$ methanol and stained with a solution of $1 \mathrm{mg} / \mathrm{ml}$ Fast Red TR salt TM (Sigma) and 200 $\mu \mathrm{g} / \mathrm{ml}$ Napthol AS-MX phosphate (Sigma) in o.1 M Tris $\mathrm{pH}$ 9.2 .

\section{Plasmids and transfections}

Nanog promoter/enhancer fragments were cloned upstream of the luciferase reporter gene in the pGL3-basic vector (Promega Madison, WI, USA). A -966/+50 fragment was obtained by PCR and was cloned in the pGL3 vector. Primers used were: forward, 5'-AGCACAAGGACTGATCGG-3', reverse, 5'-GCAGCCTTCCCACAGAAAG-3'. The enhancer fragment was obtained by PCR and was cloned in front of the -966 fragment in the pGL3 vector. Primers used were: forward, 5'-ATATAGGTACCCCCCTCCCCCACCTGTCCC-3', reverse, 5'-TATATGCTAGCG GCCACATAGCCTTAAGT-3'. For $-220 /+50$ construction, $-966 /+50$ was digested with Hin$\mathrm{dIII}$ and the excised fragment was cloned in the pGL3 vector. CGR8 cells were transfected using Lipofectamine 2000 (Invitrogen, Carlsbad, CA, USA)). The full length Nanog cDNA plasmid was kindly provided by P Savatier.

\section{Chromatin immunoprecipitation assays}

ES cells and EBs were fixed with $1 \%$ formaldehyde for 10 minutes at room temperature and the reaction was quenched by adding glycine to a final concentration of $0.125 \mathrm{M}$. ES cells were washed once with ice-cold phosphate-buffered saline (PBS), harvested and washed two more times. EBs were also washed three times with ice-cold PBS. ES cells and EBs were resuspended in lysis buffer ( $1 \%$ SDS, $10 \mathrm{mM}$ EDTA, $50 \mathrm{mM}$ Tris- $\mathrm{HCl} \mathrm{pH}$ 8.0, $1 \mathrm{mM}$ phenylmethylsulphonyl fluoride (PMSF), $1 \mathrm{ml} / 10^{6}$ cells) and incubated on ice for 10 minutes. 
The suspension was sonicated 5 times for 1 minute each and $10 \mu \mathrm{l}$ samples were analyzed by gel electrophoresis $(1.5 \%$ agarose). Properly sonicated samples were centrifuged at 14,000 $\mathrm{rpm}, 4^{\circ} \mathrm{C}$ for 15 minutes and the supernatant was stored at $80^{\circ} \mathrm{C}$. We kept $10 \mu \mathrm{l}$ from each sample as input and $50 \mu \mathrm{l}$ were immunoprecipitated with $5 \mu \mathrm{g}$ of relevant antibodies in RIPA buffer (1\% Triton X-100, 0.1\% deoxycholate (DOC), $140 \mathrm{mM}$ $\mathrm{NaCl}, 1 \mathrm{mM}$ PMSF) overnight at $4^{\circ} \mathrm{C}$ under rotation. Protein $\mathrm{G}$ beads were incubated in the same conditions with $100 \mu \mathrm{g} /$ $\mathrm{ml}$ sonicated salmon sperm DNA and $1 \mu \mathrm{g} / \mathrm{ml}$ bovine serum albumin in RIPA buffer. Blocked beads and immunoprecipitated samples were combined next day and were incubated under rotation for $3 \mathrm{~h}$ at $4^{\circ} \mathrm{C}$. The immunoprecipitates were then washed 7 times with RIPA wash buffer (1\% Triton-X, $0.1 \%$ DOC, 0.1\% SDS, $500 \mathrm{mM} \mathrm{NaCl}, 1 \mathrm{mM}$ PMSF). Input samples and beads were resuspended in $100 \mu \mathrm{l}$ of $10 \mathrm{mM}$ Tris$\mathrm{HCl}$ pH 8.0, 1 mM EDTA (TE) buffer supplemented with $0.5 \%$ SDS and proteinase $\mathrm{K}$ to a final concentration of $200 \mu \mathrm{g} / \mathrm{ml}$ and incubated for $3 \mathrm{~h}$ at $55^{\circ} \mathrm{C}$ and overnight at $65^{\circ} \mathrm{C}$. The next day samples were phenol-chloroform extracted and ethanol immunoprecipitated with $\mathrm{NaOAc}$ and $20 \mathrm{mg}$ of glycogen as a carrier. DNAs from input and immunoprecipitate pellets were resuspended in $50 \mu \mathrm{l}$ and $250 \mu \mathrm{l}$ of TE buffer, respectively. The DNA content was analyzed using real-time PCR (5 $\mu \mathrm{l} / 20 \mu \mathrm{l}$ reaction). The primers used were: Nanog promoter sense, 5'-CTTACTAAGTAGCCCAGTC-3'; Nanog promoter antisense, 5'-GTTTATACACGGTTCTTT-3'; Nrob1 promoter sense, 5'-AGTTGGAACAGAGCCCTAAC-3'; Nrob1 promoter antisense, 5'-GCCTTTGGTTGAATGTG-3'; Sall1 promoter sense, 5'-TGCGACATGGGTCCTGAG-3'; Sall1 promoter antisense, 5'-AATTCTGGAGCGCCTTTGAGT-3'; Hoxa1 promoter sense, 5'-GAGCGCGCGTCACCTACAC-3'; Hoxa1 promoter antisense, 5'-CTGAGCCGCCTGCGAAAGTT-3'; Pdgfrb promoter sense, 5'-GCAGGCAGGAGACTGACGA-3'; Pdgfrb promoter antisense, 5'-AGTCCCGGCTACCCTATCTGG-3'; Mlf 1 promoter sense, 5'-TGCCATAGCAGCCGAGCGAT-3'; Mlf1 promoter antisense, 5'-GCTTGACGCAGGCCGTTTC-3'.

\section{RNA purification and RT-PCR}

RNA was prepared using the Trizol reagent (GIBCO-BRL, Invitrogen Corp., Carlsbad, CA, USA). RT reactions were performed with Moloney murine leukemia virus from Finnzymes (Finnzymes, Espoo, Finland). SYBR Green I and Opticon monitor system from MJ Research (MJ Research, Waltham, MA USA) were used for real-time PCR reactions. Primers used for RT-PCR reactions were: Nanog sense, 5'-CGCTGCTCCGCTCCATAACT-3'; Nanog antisense, 5'-GCGCATGGCTTTCCCTAGTG-3'; Nrob1 sense, 5'-CTGGTGTGCAGCGTCTGA-3'; Nrob1 antisense, 5'-GTGTTGGTCTCCGGATCTC-3'; Sall1 sense, 5'-AGTTCTCCCAGGAGGCGAGGTG-3'; Sall1 antisense, 5'-GGTTGGCAGATGTTCGTAAAGT-3'; Hoxa1 sense, 5'-GGTCAACCCAACGCAGTG-3; Hoxa1 antisense, 5 '-TGCTTCATGCGGCGATT-3'; Pdgfr $\beta$ sense, 5'-GACTACCTGCACCGGAACA-3'; $P d g f r \beta$ antisense, 5'-GGGACTCAATGTCTGCGTATT-3'; Mlfi sense, 5'-GAACCCATAATCGTCGAG-3'; Mlf1 antisense, 3'CTTCGGGTTTGAGTTGAG-3'; Sox17 sense, 5'-CTCTGCCCT-
GCCGGGATGG-3'; Sox17 antisense, 5'-AATGTCGGGGTAGTTGCAATA-3'; Brachyury sense, 5'GCGAGCTGGGTGGATGTAGA-3'; Brachyury antisense, 5'CAAGGCGGCACAAGACTAAGTC-3; Mash1 sense, 5'-CCACCATCTCCCCCAACTA-3'; Mash1 antisense, 5'-CTGGGCTAAGAGGGTCGTAGG-3'; Hprt sense, 5'CTCCTCAGACCGCTTTTTG-3'; Hprt antisense, 5'-TCCTCGGCATAATGATTAGG-3'.

\section{Protein and histone extracts}

CGR8 cell extracts were prepared using a lysis buffer containing $50 \mathrm{mM}$ Tris 8.0, $170 \mathrm{mM} \mathrm{NaCl}, 50 \mathrm{mM} \mathrm{NaF}, 0.5 \% \mathrm{NP}-40$, $1 \mathrm{mM}$ PMSF. For histone extraction, cells were harvested, washed three times with ice-cold PBS supplemented with 5 $\mathrm{mM} \mathrm{Na}$ butyrate and lysed with a Triton extraction buffer (PBS supplemented with $0.5 \%$ Triton, $2 \mathrm{mM}$ PMSF, $0.02 \%$ $\mathrm{NaN} 3$ ) at a cell density of $10^{7}$ cells $/ \mathrm{ml}$. The lysate was centrifuged at 2,000 rpm for 10 minutes at $4^{\circ} \mathrm{C}$, and the pellet was washed twice with a half Triton extraction buffer volume and then resuspended in $0.2 \mathrm{~N} \mathrm{HCl}$ at a cell density of $4 \times 10^{7}$ cells $/ \mathrm{ml}$. Histones were acid extracted overnight at $4^{\circ} \mathrm{C}$. The next day samples were centrifuged at 2,00o rpm for $10 \mathrm{~min}-$ utes at $4^{\circ} \mathrm{C}$ and the supernatant was dialyzed against $\mathrm{CH}_{3} \mathrm{COOH}$ and $\mathrm{H}_{2} \mathrm{O}$. Samples were kept at $-80^{\circ} \mathrm{C}$ with $20 \%$ glycerol.

\section{Microarray hybridization}

Total RNA from ES cells was isolated using the RNeasy Mini Kit from QIAGEN (QIAGEN GmbH, Hilden, Germany) and treated with RNase-free DNase I ( $5 \mathrm{U} / 100 \mu \mathrm{g}$ of nucleic acids, Sigma). Biotinylated cRNA was prepared according to the standard Affymetrix protocol. In brief, double-stranded cDNA was synthesized from $10 \mu \mathrm{g}$ total RNA using the SuperScript Choice System from Invitrogen and the Affymetrix $\mathrm{T}_{7-}(\mathrm{dT})_{24}$ primer, which contains a $\mathrm{T} 7 \mathrm{RNA}$ polymerase promoter attached to a poly-dT sequence. Following a phenol/chloroform extraction and ethanol precipitation, the cDNA was transcribed into biotin-labeled cRNA using the Retic Lysate IVT ${ }^{\mathrm{TM}}$ kit (Ambion Inc., Woodward Austin, TX, USA). cRNA products were purified using the RNeasy kit (QIAGEN) and fragmented to an average size of 30-50 bases according to Affymetrix recommendations. Fragmented cRNA (15 $\mu \mathrm{g})$ was used to hybridize the Mouse Genome 430 2.0 Array for $16 \mathrm{~h}$ at $45^{\circ} \mathrm{C}$. The arrays were washed and stained in the Affymetrix Fluidics Station 400 and scanned using the Hewlett-Packard GeneArray Scanner G2500A.

\section{Microarray data analysis}

The image data were analyzed with the GeneChip ${ }^{\circledR}$ Operating Software (GCOS) using Affymetrix default analysis settings. After a quality control test, arrays were normalized by log scale robust multi-array analysis (RMA) [44].

A parametric ANOVA (F-test) was performed. The false discovery rate of the resulting test-set was calculated using the Benjamini Hochberg procedure [45]. An f-test $p$-value $<10^{-2}$ 
corresponding to a false discovery rate of $4.066 \times 10^{-2}$ and a fold change $>2$ was used in order to select transcripts appearing in Additional data file 2 (792 down-regulated and 1,376 up-regulated transcripts). For the hierarchical clustering, a ftest $p$-value $<10^{-3}$, corresponding to a false discovery rate of $7.833 \times 10^{-3}$ and a fold change $>4$ between the control and TSA treatment at $6 \mathrm{~h}$ or $12 \mathrm{~h}$ was used to identify and restrict the number of differentially expressed genes (fold change $>4$, 458 probe sets). We then performed hierarchical clustering of the above 458 probesets to identify genes that respond similarly to the various experimental conditions. The cluster analysis was done using cluster version 2.11 [46] applying meancentering and normalization of genes and arrays before average linkage clustering with uncentered correlation. The expression profiles of differentially expressed transcripts were discriminated into four groups according to the expression profile of the hierarchical clustering.

Functional annotation of transcripts differentially expressed $\geq 4$-fold was done using the Database for Annotation, Visualization, and Integrated Discovery (DAVID) [31] to obtain Gene Ontology annotations for the category of 'biological process'. Transcript redundancies were removed based on statistical analysis and PCR validation data.

\section{Abbreviations}

$\mathrm{H}_{3} \mathrm{~K} 27$, Histone 3 lysine 27, $\mathrm{H}_{3} \mathrm{~K} 4$, Histone 3, lysine 4; ALP, alkaline phosphatase; ChIP, chromatin immunoprecipitation; EB, embryoid body; ES, embryonic stem; ESre, ES released from TSA; PBS, phosphate-buffered saline; TSA, trichostatin A.

\section{Authors' contributions}

EK performed experiments, analyzed data, produced figures and tables and contributed to the writing of the manuscript. $\mathrm{HS}$, $\mathrm{OH}$ performed and $\mathrm{NH}$ guided the Affymetrix microarray analysis. AKH contributed to data analysis and manuscript organization. AK designed experiments, analyzed data and wrote the manuscript. All authors had the opportunity to discuss the results and comment on the manuscript.

\section{Additional data files}

The following additional data are available with the online version of this paper. Additional data file 1 includes supplemental materials and methods, and Figures S1-S7. Additional data file 2 lists gene probesets that show $\geq 2$-fold change in their mRNA levels after treatment of mouse ES cells with 50 $\mathrm{nM}$ of TSA for 6 and $12 \mathrm{~h}$. Additional data file 3 lists gene probesets that show $\geq 4$-fold change in their mRNA levels after treatment of mouse ES cells with $50 \mathrm{nM}$ of TSA for 6 and $12 \mathrm{~h}$, categorized according to their kinetics. Additional data file 4 lists the functional annotation of gene probesets of subcluster 1a based on biological process. Additional data file
5 lists the functional annotation of gene probesets of subcluster $1 \mathrm{~b}$ based on biological process. Additional data file 6 lists the functional annotation of gene probesets of subcluster $2 \mathrm{a}$ based on biological process. Additional data file 7 lists the functional annotation of gene probesets of subcluster $2 b$ based on biological process.

\section{Acknowledgements}

We thank V Makatounakis, G Vretzos and S Schmidt for technical assistance, $P$ Savatier and $A$ Sachinidis for reagents and unpublished information, C Deligianni, C Doxaki, A Zaragoulias and G Vlastos for constructs. Special thanks to J Papamatheakis for critical reading of the manuscript, M Gialitakis, J Vilo and R Kolde for data analysis. This work was supported by the EU FP6 I.P FunGenES Grant LSHG-CT 2003-503494 (AK, AKH, NH, FB), IMBB (AK), Vanderbilt University and NIH HL083958 Grant (AKH).

\section{References}

I. Boiani M, Scholer HR: Regulatory networks in embryo-derived pluripotent stem cells. Nat Rev Mol Cell Biol 2005, 6:872-884.

2. Niwa H: How is pluripotency determined and maintained? Development 2007, 134:635-646.

3. Niwa H, Burdon T, Chambers I, Smith A: Self-renewal of pluripotent embryonic stem cells is mediated via activation of STAT3. Genes Dev 1998, 12:2048-2060.

4. Ying QL, Nichols J, Chambers I, Smith A: BMP induction of Id proteins suppresses differentiation and sustains embryonic stem cell self-renewal in collaboration with STAT3. Cell 2003, I I 5:28I-292.

5. Sato N, Meijer L, Skaltsounis L, Greengard P, Brivanlou AH: Maintenance of pluripotency in human and mouse embryonic stem cells through activation of Wnt signaling by a pharmacological GSK-3-specific inhibitor. Nat Med 2004, 1 0:55-63.

6. Boyer LA, Lee TI, Cole MF, Johnstone SE, Levine SS, Zucker JP, Guenther MG, Kumar RM, Murray HL, Jenner RG, Gifford DK, Melton DA, Jaenisch R, Young RA: Core transcriptional regulatory circuitry in human embryonic stem cells. Cell 2005, I 22:947-956.

7. Loh YH, Wu Q, Chew JL, Vega VB, Zhang W, Chen X, Bourque G, George J, Leong B, Liu J, Wong KY, Sung KW, Lee CW, Zhao XD, Chiu KP, Lipovich L, Kuznetsov VA, Robson P, Stanton LW, Wei CL, Ruan Y, Lim B, Ng HH: The Oct4 and Nanog transcription network regulates pluripotency in mouse embryonic stem cells. Nat Genet 2006, 38:43 I-440.

8. Takahashi K, Yamanaka S: Induction of pluripotent stem cells from mouse embryonic and adult fibroblast cultures by defined factors. Cell 2006, I 26:663-676.

9. Zhang J, Tam WL, Tong GQ, Wu Q, Chan HY, Soh BS, Lou Y, Yang J, Ma Y, Chai L, Ng HH, Lufkin T, Robson P, Lim B: Sall4 modulates embryonic stem cell pluripotency and early embryonic development by the transcriptional regulation of Pou5fI. Nat Cell Biol 2006, 8: I I 4- I I 23.

10. Ivanova N, Dobrin R, Lu R, Kotenko I, Levorse J, DeCoste C, Schafer $X$, Lun $Y$, Lemischka IR: Dissecting self-renewal in stem cells with RNA interference. Nature 2006, 442:533-538.

II. Wang J, Rao S, Chu J, Shen X, Levasseur DN, Theunissen TW, Orkin $\mathrm{SH}$ : A protein interaction network for pluripotency of embryonic stem cells. Nature 2006, 444:364-368.

12. Fischle W, Wang Y, Allis CD: Histone and chromatin cross-talk. Curr Opin Cell Biol 2003, I 5: 172-183.

13. Margueron R, Trojer P, Reinberg D: The key to development: interpreting the histone code? Curr Opin Genet Dev 2005, 15:163-176.

14. Kouzarides T: Chromatin modifications and their function. Cell 2007, I 28:693-705.

15. Meshorer E, Yellajoshula D, George E, Scambler PJ, Brown DT, Misteli T: Hyperdynamic plasticity of chromatin proteins in pluripotent embryonic stem cells. Dev Cell 2006, 10:105-II6.

16. Mikkelsen TS, Ku M, Jaffe DB, Issac B, Lieberman E, Giannoukos G, Alvarez P, Brockman W, Kim TK, Koche RP, Lee W, Mendenhall E, O'Donovan A, Presser A, Russ C, Xie X, Meissner A, Wernig M, Jaenisch R, Nusbaum C, Lander ES, Bernstein BE: Genome-wide maps of chromatin state in pluripotent and lineage-committed 
cells. Nature 2007, 448:553-560.

17. Pan J, Tian S, Nie J, Yang C, Ruotti V, Wei H, Jonsdottir G, Stewart R, Thomson J: Whole-genome analysis of histone $\mathrm{H} 3$ lysine 4 and lysine $\mathbf{2 7}$ methylation in human embryonic stem cells. Cell Stem Cell 2007, I:299-312.

18. Lee TI, Jenner RG, Boyer LA, Guenther MG, Levine SS, Kumar RM, Chevalier B, Johnstone SE, Cole MF, Isono K, Koseki H, Fuchikami T, Abe K, Murray HL, Zucker JP, Yuan B, Bell GW, Herbolsheimer E, Hannett NM, Sun K, Odom DT, Otte AP, Volkert TL, Bartel DP, Melton DA, Gifford DK, Jaenisch R, Young RA: Control of developmental regulators by Polycomb in human embryonic stem cells. Cell 2006, I25:30I-3|3.

19. Boyer LA, Plath K, Zeitlinger J, Brambrink T, Medeiros LA, Lee TI, Levine SS, Wernig M, Tajonar A, Ray MK, Bell GW, Otte AP, Vidal M, Gifford DK, Young RA, Jaenisch R: Polycomb complexes repress developmental regulators in murine embryonic stem cells. Nature 2006, 44I:349-353.

20. Bernstein BE, Mikkelsen TS, Xie X, Kamal M, Huebert DJ, Cuff J, Fry B, Meissner A, Wernig M, Plath K, Jaenisch R, Wagschal A, Feil R, Schreiber SL, Lander ES: A bivalent chromatin structure marks key developmental genes in embryonic stem cells. Cell 2006, I 25:3।5-326.

21. Azuara V, Perry P, Sauer S, Spivakov M, Jørgensen HF, John RM, Gouti M, Casanova M, Warnes G, Merkenschlager M, Fisher AG: Chromatin signatures of pluripotent cell lines. Nat Cell Biol 2006, 8:532-538.

22. Zhao XD, Han X, Chew JL, Liu J, Chiu KP, Choo A, Orlov YL, Sung WK, Shahab A, Kuznetsov VA, Bourque G, Oh S, Ruan Y, Ng HH, Wei CL: Whole-genome mapping of histone H3 Lys4 and 27 trimethylations reveals distinct genomic compartments in human embryonic stem cells. Cell Stem Cell 2007, I:286-298.

23. Barski A, Cuddapah S, Cui K, Roh TY, Schones DE, Wang Z, Wei G, Chepelev I, Zhao K: High-resolution profiling of histone methylations in the human genome. Cell 2007, 129:823-837.

24. Spivakov M, Fisher AG: Epigenetic signatures of stem-cell identity. Nat Rev Genet 2007, 8:263-27I.

25. Bernstein BE, Meissner A, Lander ES: The mammalian epigenome. Cell 2007, I28:669-68I.

26. Surani MA, Hayashi K, Hajkova P: Genetic and epigenetic regulators of pluripotency. Cell 2007, I 28:747-762.

27. Torres-Padilla ME, Parfitt DE, Kouzarides T, Zernicka-Goetz M: Histone arginine methylation regulates pluripotency in the early mouse embryo. Nature 2007, 445:2 14-2/8.

28. Wu Q, Chen X, Zhang J, Loh YH, Low TY, Zhang W, Zhang W, Sze SK, Lim B, Ng HH: Sall4 interacts with Nanog and co-occupies Nanog genomic sites in embryonic stem cells. J Biol Chem 2006, 281:24090-24094.

29. Kuroda T, Tada M, Kubota $\mathrm{H}$, Kimura $\mathrm{H}$, Hatano SY, Suemori $\mathrm{H}$, Nakatsuji N, Tada T: Octamer and Sox elements are required for transcriptional cis regulation of Nanog gene expression. Mol Cell Biol 2005, 25:2475-2485.

30. Rodda DJ, Chew JL, Lim LH, Loh YH, Wang B, Ng HH, Robson P: Transcriptional regulation of nanog by OCT4 and SOX2. J Biol Chem 2005, 280:2473I-24737.

31. Dennis G Jr, Sherman BT, Hosack DA, Yang J, Gao W, Lane HC, Lempicki RA: DAVID: Database for Annotation, Visualization, and Integrated Discovery. Genome Biol 2003, 4:P3.

32. Lee ER, Murdoch FE, Fritsch MK: High histone acetylation and decreased polycomb repressive complex 2 member levels regulate gene specific transcriptional changes during early embryonic stem cell differentiation induced by retinoic acid. Stem Cells 2007, 25:2191-2199.

33. Taddei A, Roche D, Bickmore WA, Almouzni G: The effects of histone deacetylase inhibitors on heterochromatin: implications for anticancer therapy? EMBO Rep 2005, 6:520-524.

34. Gregory RI, O'Neill LP, Randall TE, Fournier C, Khosla S, Turner BM, Feil R: Inhibition of histone deacetylases alters allelic chromatin conformation at the imprinted U2afI-rsI locus in mouse embryonic stem cells. J Biol Chem 2002, 277: I I728-1 I734.

35. Lee $J \mathrm{H}$, Hart $\mathrm{SR}$, Skalnik DG: Histone deacetylase activity is required for embryonic stem cell differentiation. Genesis 2004, 38:32-38.

36. Kawamura T, Ono K, Morimoto T, Wada H, Hirai M, Hidaka K, Morisaki T, Heike T, Nakahata T, Kita T, Hasegawa K: Acetylation of GATA-4 is involved in the differentiation of embryonic stem cells into cardiac myocytes. J Biol Chem 2005, 280: I9682-19688.

37. Balasubramaniyan V, Boddeke E, Bakels R, Kust B, Kooistra S, Veneman A, Copray S: Effects of histone deacetylation inhibition on neuronal differentiation of embryonic mouse neural stem cells. Neuroscience 2006, I43:939-95I.

38. McCool KW, Xu X, Singer DB, Murdoch FE, Fritsch MK: The role of histone acetylation in regulating early gene expression patterns during early embryonic stem cell differentiation. J Biol Chem 2007, 282:6696-6706.

39. Zupkovitz G, Tischler J, Posch M, Sadzak I, Ramsauer K, Egger G, Grausenburger R, Schweifer N, Chiocca S, Decker T, Seiser C: Negative and positive regulation of gene expression by mouse histone deacetylase I. Mol Cell Biol 2006, 26:79/3-7928.

40. Schuettengruber B, Chourrout D, Vervoort M, Leblanc B, Cavalli G: Genome regulation by polycomb and trithorax proteins. Cell 2007, I 28:735-745.

4I. Christensen J, Agger K, Cloos PA, Pasini D, Rose S, Sennels L, Rappsilber J, Hansen KH, Salcini AE, Helin K: RBP2 belongs to a family of demethylases, specific for tri-and dimethylated lysine 4 on histone 3. Cell 2007, I 28:1063-1076.

42. Agger K, Cloos PA, Christensen J, Pasini D, Rose S, Rappsilber J, Issaeva I, Canaani E, Salcini AE, Helin K: UTX and JMJD3 are histone H3K27 demethylases involved in HOX gene regulation and development. Nature 2007, 449:73I-734.

43. Swigut T, Wysocka J: H3K27 demethylases, at long last. Cell 2007, I3 I:29-32.

44. Irizarry RA, Bolstad BM, Collin F, Cope LM, Hobbs B, Speed TP: Summaries of Affymetrix GeneChip probe level data. Nucleic Acids Res 2003, 3 I: I5.

45. Benjamini $Y$, Hochberg Y: Controlling the false discovery rate: a practical and powerful approach to multiple testing. J Roy Statist Soc Ser B 1995, 57:289-300.

46. Eisen MB, Spellman PT, Brown PO, Botstein D: Cluster analysis and display of genome-wide expression patterns. Proc Natl Acad Sci USA 1998, 95:|4863-|4868. 